\title{
ARCHITECTURE TRADITION AND MODERNITY OF THE BUILDING GEDHE MATARAM MOSQUE KOTAGEDHE YOGYAKARTA
}

\author{
Baharrudin Purbahanggita*1, Eddy Prianto ${ }^{2}$ \\ Departement of Architecture Diponegoro University \\ *Correspondence author: baharrudinpa@students.undip.ac.id, Yogyakarta, Indonesia
}

\begin{abstract}
Indonesia has various kinds of cultural wealth. The richness of this culture is most easily seen in the architectural works that have characteristics. One example of traditional Indonesian architectural work is Javanese architecture, especially the legacy of the Islamic Mataram Kingdom. Architectural works that can still be seen and used today are mosque worship buildings. Research at the Mataram Gedhe Mosque has not been found much so that it is appropriate to be the object of research. This research begins with a search for qualitative data in the form of interviews with participants. Existing data collection is done by taking pictures at several points of the mosque as well as on the details of the existing ornaments at the Mataram Gedhe Mosque. Mataram Gedhe Mosque as a place of worship is still bound by the architectural tradition of Javanese mosques. However, the Mataram Gedhe Mosque still has its novelty. Newness in architecture is an indicator of architectural modernity. The value of architectural novelty at the Mataram Gedhe Mosque is hoped to be a lesson in architectural design.
\end{abstract}

Keywords: Traditional Architecture, Mataram Gedhe Mosque, Modernity

\section{Introduction}

Indonesia has various kinds of cultural wealth that are scattered throughout the geographical area of Indonesia. The richness of this culture is most easily seen in the architectural works that have characteristics. One example of traditional Indonesian architectural work is Javanese architecture, especially the legacy of the Mataram Islamic kingdom. Today's Islamic Mataram architectural works of art that are still preserved and are characteristic of it can be easily found in Yogyakarta. The mosque in Yogyakarta, which is still close to the palace, clearly has a Javanese architectural style that was influenced by the Mataram Islamic kingdom. The mosque that is still very clear about the cultural features of the Mataram Islamic Sultanate is the Mataram Gedhe Mosque. Mataram Gedhe Mosque is an ancient mosque, a cultural relic of the past whose existence is still sustainable until now, even functionally it can still be used for worship. The research will focus more on the discussion of architectural traditions and architectural modernity in mosques. Osborne (2010) defines modernity as an idea that highlights the novelty that occurs in the present as a separation or a break with the past, and opens hope for the future quickly, but not with certainty.

Rosyadi (2015) which argues that in the midst of exploitation of the natural environment which is carried out by "advanced people" using sophisticated equipment and technology, there are community groups or communities with knowledge. local and traditional institutions that are all unpretentious are able to preserve the environment. Of the majority of these communities the greatest in maintaining traditional values are the indigenous peoples. Latif 
(2011) which explains that indigenous peoples as groups of people who live in a certain geographic area for a relatively long period of time, are bound to traditions and customs inherited from their ancestors, among their members are bound by kinship.

Culture and traditions that are believed by certain people from generation to generation are also related to the environment in which they live. Especially in architectural science, there are traditional values that are still maintained by the community because there are meanings and philosophies in each of its elements. Budihardjo (1987) which explains that the spatial layout and physical forms of traditional architecture always refer to non-physical aspects, such as customs, beliefs, and religions. Cecep (2010: 74) which explains that the embodiment of the above concepts appears in the form of uniqueness in every work of traditional houses in the archipelago.

Budihardjo (1987) explains that each tribe has its own characteristics related to the form of traditional houses and traditional houses that are used as residences by certain individuals and groups of people. In the process of maintaining and preserving the characteristics and values of traditional houses, each tribe or community group has a cultural heritage in the form of a philosophy that is used as a guide for building a house (Rosyadi 2015). According to the Central Statistics Agency (BPS) and the Institute of Southeast Asian Studies (ISEAS) related to ethnic and ethnic groupings in Indonesia, with the distribution of around 633 ethnic groups making Indonesia a country rich in culture (Pitoyo and Triwahyudi 2017). Arinto (2018) which explains that local architecture is a source architecture that can be used as a guideline for contemporary architecture or Kiwari architecture. Salura and Lake (2014) without losing the cultural meaning of a building and even the area.

Osborne (2010) defines modernity as the idea of highlighting the newness that is happening now as a separation or a break with the past, as well as opening up hope for the future quickly, but not with certainty. Modernity is very thick with innovation and progress in development against ancient values and ideas from the previous era. Modernity arises from the term in the social and humanities field which means that modernity is not a pure term in the scientific field of architecture. Although it has a major role and impact in the development of architectural science (Madsen, 2014). Experts who talk about modernity, from Karl Marx to Daniel Bell, argue that modernity is the welcome of economic development which ultimately brings about broad super-structural changes, for example social and cultural changes (Mondal, 2014). The development of modernity in general appeared in 5 stages during the development of European civilization. The development of Modernity cannot be separated from modernism in the world of architecture. View of modernism architecture also focuses rejection traditionality and historical, as well as continuously develop novelty design concept which is based on the shape(form)and use(function)(Capon, 1999). Modernism emphasizes the context and function of buildings rather than ornaments and decorations that beautify the building. In the development of modernism, the theory of modernism which is always used as a reference is the theory of Le Corbusier which explains that the core of the building is 3 aspects, namely mass, which means the basic shape of the building that wants to be designed is generally a geometric shape. The building envelope is an identity and a form of originality of the designer and the plan as the core of the building which will have an impact on the comfort of use because it relates to circulation and the relationship between humans and space (Corbusier, 1931).

Mosque Gedhe Mataram Mosque is the oldest mosque in Yogyakarta. Located in the south of the Kotagede Market area now, to be precise in Jagalan village, Banguntapan subdistrict, Bantul. Kotagede Mosque was built during the Mataram Kingdom era in 1640 by Sutan Agung together with local people who are generally Hindu and Buddhist. This mosque has an inscription which states that the mosque was built in two stages. The first stage was built during the Sultan Agung era only in the form of the core building of the mosque which was 
small so that it was called langgar. The second stage of the mosque was built by the King of Kasunanan Surakarta, Paku Buwono X. The different parts of the mosque built by the Sultan Agung and Paku Buwono $X$ are on the pillars. The part that was built by Sultan Agung had wooden poles while those that were built by Paku Buwono had iron poles. This mosque is still alive today. Residents still use it as a place to carry out religious activities. This mosque building is a form of tolerance by Sultan Agung when the residents who participated in building the mosque embraced Hinduism and Buddhism. Hindu and Buddhist characteristics still clearly influence the building of this mosque, such as a gate shaped like a paduraksa. The core building of the mosque is a Javanese pyramid-shaped building, its characteristics can be seen on the pyramid-shaped roof and the room which is divided into two, namely the core and the foyer.

Mallgrave (2006) argues that although the renaissance is an intellectual upheaval that is broader than its development in a single area or humanist perspective, there are many reasons to set the development (architecture) of Central Italy as a precedent. The renaissance period is an example that can be taken as learning material. Because from this period there were many relevant theories as the basis for the architectural design process. So that the more theories that are understood, especially theories regarding architectural science from the past, the more understanding will be about the principles of architectural modernity.

Architectural criticism only concentrates on a building only. However, over time it is realized that a building is in a broader context. Thus the scope of the discussion of architectural criticism also penetrates urban design and planning, as well as design production activities (Attoe, 1999). In general, architectural criticism has a basic role that can be useful in the future. The first basic role is as a descriptive role, namely as an activity to review architectural works including in the production section. The next role as interpretation is the activity of providing suggestions from various points of view so that the work can be produced properly. The last role is as evaluation, namely the activity of objectively assessing architectural works which can be used as a reference for evaluating the success of the architectural design process.

Architectural theory has various types including :

1. Prescriptive which is an effort to offer new solutions which can then be used as standards or norms in the design process.

2. Proscriptive is an effort that can be used as an appeal so that the design process is avoided. These efforts are more inclined to describe the negative impacts of the design process.

3. Affimative, namely an effort to conduct cross-scientific studies and the relationships arising from the design process so that the resulting results can accommodate various kinds of parties (Neisbit, 1996).

\section{Methods}

The research begins with a search for qualitative data in the form of interviews with participants. The interview contains questions about the existing conditions of the mosque, renovations and changes that have been made to the mosque, the history of the mosque to the philosophical values that exist in the elements of the mosque. Existing data collection is also done by taking pictures at several points of the mosque as well as on the details of the existing ornaments at the Mataram Gedhe Mosque. The study ended with data analysis, which was then analyzed with a literature review approach until finally getting the final conclusion of the study. 


\section{Result and Discussion}

\section{Historical Study of Mataram Mosque Gedhe}

Mosque as a place of worship is one type of architectural building that is easily found in Indonesia. The mosque is often used as a communal space by local residents to interact with each other. With so many activities that can be done in a mosque, the typology of the mosque is very different from other buildings of worship. So that the mosque can be said to be one of the works of Islamic architecture. This is supported by Hattstein (2004) who explains that mosques can be called Islamic architectural buildings.

The shape and design of mosques in Indonesia, especially in Yogyakarta, are the result of acculturation of pre-Islamic culture in Yogyakarta. Before the Indonesian people recognized Islam, other religions such as Hinduism and Buddhism existed beforehand as well as animism and dynamism customary beliefs. Thus, it is not surprising that the shape and design of the mosque still contains elements of cultural acculturation originating from previous religions. The Mataram Gedhe Mosque has a dominant design and shape with the temple building at the entrance gate. Apart from being influenced by the cultural acculturation around the shape and design of the mosque, it is also inseparable from natural conditions such as topography, climate, and other geographical conditions. The most obvious effect that can be seen is the use of a tajug roof with wooden horses which is very appropriate for use in tropical areas, one of which is in Yogyakarta. This is reinforced by Prijotomo (1999) \& Josef Prijotomo (1984) who state that Pre-Islamic Culture is Hindu-Buddhist culture and animism-dynamism. This Islamic and pre-Islamic culture also colored the architectural character in Indonesia. Among them are the architectural character of the mosque. Apart from Islamic and pre-Islamic cultures, the diversity of mosque architecture in Indonesia is also influenced by climatic conditions, topography, geography and local culture.

Setyowati et al (2017) argue that the mosque building was first erected by the Prophet Muhammad SAW. The mosque has virtue in Islam, as a building "House of Allah". Mosques are used as buildings for worshiping Allah and other activities aimed at worshiping Allah. Therefore, the design of prayer rooms and foyers and courtyards in mosques can generally accommodate various activities with large numbers of visitors. Apart from that, mosques generally have a large courtyard so that non-religious activities can also be facilitated by building a mosque without disturbing its main function, namely as a place of worship. Mosques in the era of the Islamic kingdom, especially in the Mataram Kingdom, the mosque was located close to the palace and the square. With a location close to the center of government and the city center, the mosque functioned more widely during the Mataram Islamic kingdom. At the Mataram Gedhe Mosque, the location of the mosque is very close to the palace and the city center, in this case the square. This is reinforced by Setyowati et al., (2017) who explain that the Yogyakarta Mataram Gedhe Mosque has an interesting architectural style. In plain view, the architecture of the building has two characters, Hinduism and Javanese Islam. Mataram Gedhe Mosque is one of the historical legacies of the Islamic Mataram kingdom.

Based on the history of the Mataram Gedhe Mosque, it was built in the era of the Mataram Islamic kingdom, namely during the reign of Ki Ageng Arrowing. This was reinforced by Pudjiono (2003) who explained that the Gedhe Mosque was built in the XVI century by Ki Ageng Arrowing or Sunan Kalijaga, one of the guardians of Walisongo. Thus, it can be ascertained that the architect of the Mataram Gedhe Mosque was Sunan Kalijaga, who at that time also had the position of king of the Islamic Mataram Kingdom. According to Wahyudi, A., (2017) explains that the role of Sunan Kalijaga in the architecture of the Gedhe Mataram Jogjakarta Mosque is transcendental. In terms of development, Sunan Kalijaga is the foundation stone of the concept or architecture of an Islamic city, mosque building technology, 
behavior in accordance with Islamic teachings and an Islamic lifestyle. So it is not surprising that the architecture at the Mataram Gedhe Mosque nuances of Hindu-Buddhist culture is still very strong. The ornaments on the gate also have a very strong Hindu-Buddhist style. It is not surprising, given that Sunan Kalijaga is famous for preaching that uses culture to spread Islam. So thus the acculturation of culture is very strong in the architecture of the Mataram Gedhe Mosque. This is reinforced by Abimuda (2017) who explains that some of the cultures seen in the architecture of the Mataram Gedhe mosque are a form of cultural acculturation. Acculturation is a combination of two or more cultures which then produces a new culture without changing the original elements in it.

\section{Environmental Assessment and External}

Appearance of the Mataram Gedhe Mosque if grouped by function there are 2 groups of buildings, namely the main building, namely the place used for worship and the building of the foyer and patio which can be used to accommodate other non-religious activities. This is reinforced by Setyowati et al., (2017) which explains that the mosque building consists of the main building, the veranda building and the patio. Meanwhile, if it is reviewed based on the spatial layout, there is an inside layout and an outside layout with an outside layout limited by a dividing wall. According to Uwarna (1987) explains that the boundary wall of the Mataram Gedhe Mosque is a wall that has similarities to the walls of the Hindu-Buddhist temple walls.

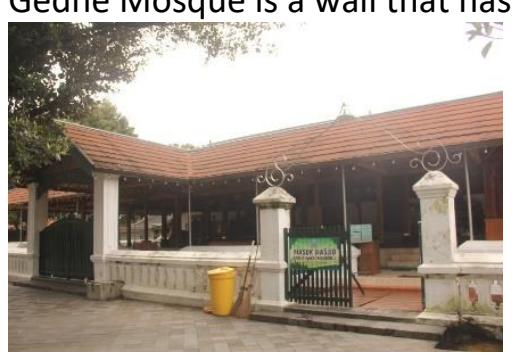

Picture 1 Front of Gedhe Mataram Mosque

Source : Personal Dokumentation

In the layout of the mosque, which is inside the dividing wall which is at the entrance gate, there are various kinds of supporting architectural elements in the mosque, one of which is the pool that surrounds the mosque. The pool that surrounds the mosque means that when entering the mosque building, you should clean yourself first because the mosque is a holy building of worship. This is reinforced by Setyowati (2007) who explains that on the inside of the wall there is a rod / perimeter pool. Jagang surrounds the mosque complex and is also around the patio of the mosque building. The meaning of Jagang around the wall of the fence as a security fort after the guardrail / fort. With the pool around the mosque, accidentally when going to the mosque the foot will be cleaned in the pool water.

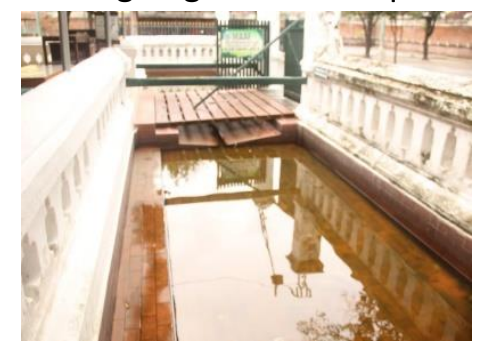

Picture 2 Jagang

Source : Personal Dokumentation

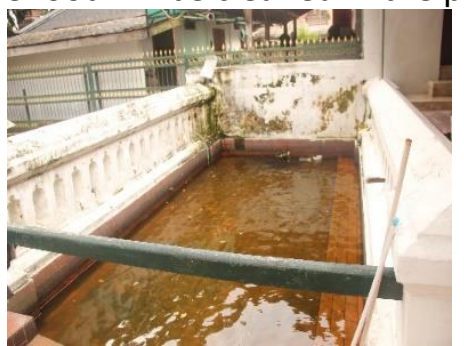




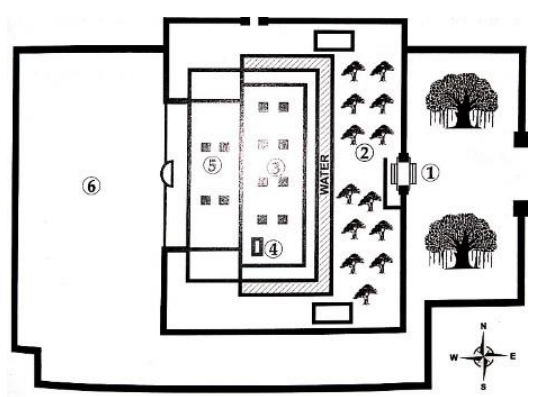

Picture 3 Siteplan of Gedhe Mataram Mosque

Source : The massage of panembahan senopati king of mataram Islamic kingdom

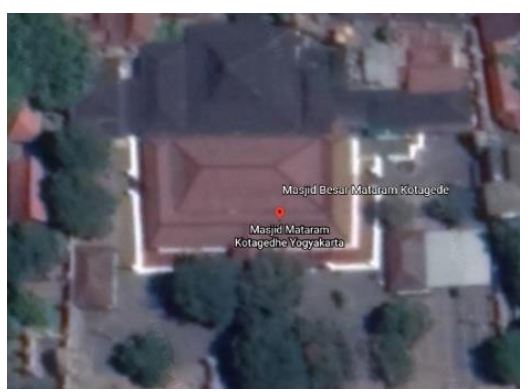

Picture 4 Satelite photo of Gedhe Mataram Mosque Source : Google Earth

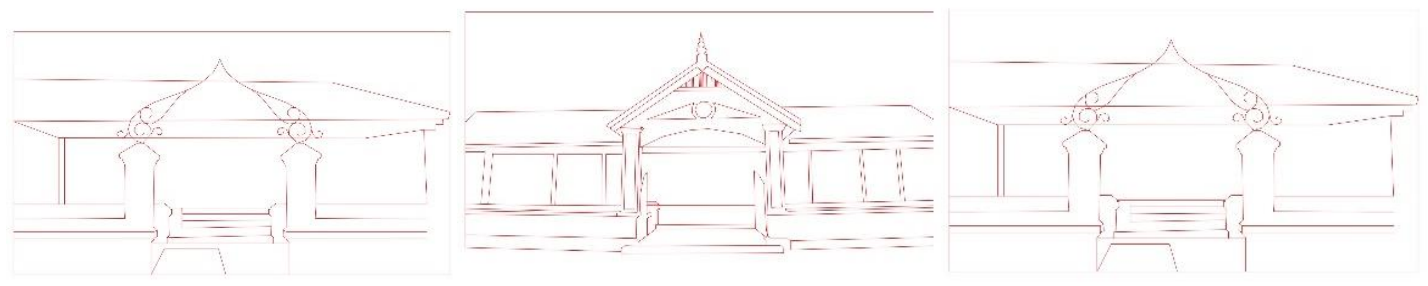

Picture 5 Sketch of Gedhe Mataram Mosque Source : Personal Sketch

The dividing wall at the mosque has 2 types of entrance gates, namely paduraksa, which is an entrance gate that looks like the gate in a Hindu-Buddhist temple. After the paduraksa there is seketeng, which is a dividing wall that shows the direction in which visitors will go. The left direction is the road leading to the king's tomb while the right direction is the road leading to the courtyard of the mosque complex. The tomb of the king which is around the Mataram Gedhe Mosque is a characteristic of the existing architecture in mosques in Java. This is reinforced by Handinoto (2012) who explains that the tomb in the mosque environment is a characteristic of ancient Javanese mosque buildings. Meanwhile, according to takmir's opinion Like S (2017) when interviewed explained that the graves in the mosque area were the tombs of the mosque founders and their families. The tomb in the Mataram Gedhe Mosque is located on the north west / northwest side of the mosque.

\section{Study of the Structure of the Prayer}

Room The prayer room which is the main building in the mosque is often referred to as the liwan. The size of the prayer room is $30 \times 30 \mathrm{~m}$ or $900 \mathrm{~m} 2$. Like other Javanese mosques in the Mataram Gedhe Mosque, the main structure that supports the building is the main column which is made of wood. There are 4 main wooden columns which are also referred to as soko guru with dimensions of $0.3 \times 0.3 \mathrm{~m}$ with a height of up to $5 \mathrm{~m}$. Meanwhile, the roof that covers the mosque building uses a hanging tajug roof which is very commonly used in 
Javanese-style buildings. The roof of the hanging tajug is supported by the load of the structure by wooden columns or a teacher's pillar. Besides that, on the divider between the liwan (the main prayer room) there is a 2 stone brick wall which also functions as a support for the roof load. So it can also be said that the main building structure of the mosque uses the stereoromic principle, namely the walls not only function as a barrier but also as a distributor of roof loads. This was reinforced by Setyowati et al., (2017) who explained that Liwan's space was limited by a 2-stone brick wall, which functions structurally to support the roof of the Hanging symbol.

\section{The structure of the Serambi and Emperors of the Mosque}

Serambi Mosque of the Gedhe Mataram Mosque is structurally different from the liwan (main building). However, the main structure still uses wooden columns called Soko Pengarep and Soko Penanggap. The column is supported by the same pedestal foundation, namely a black natural stone foundation without ornament. While on the roof using a limasan roof with wooden horses. The connection between the pyramid roof and the hanging tajug roof in the main building is connected by a gutter of a half-spherical concave iron plate. The use of iron plate gutters likely originated from Chinese carpentry that existed at that time. This is reinforced by Setyowati et al., (2017) who explain that the gutter technique with iron material is possible to be a technology from Chinese carpentry.

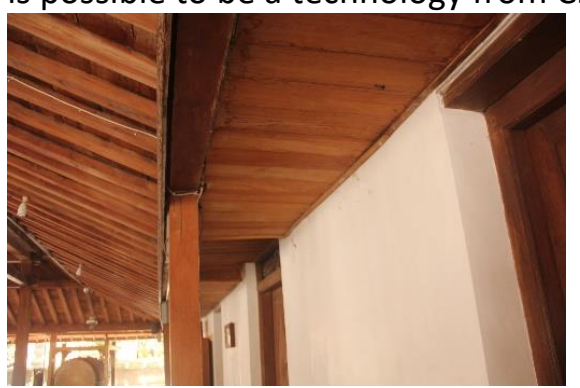

Picture 5 Connection of Tajug and Limasan roof

Source : Personal Dokumentation

In the porch, there is also a patio which has a pyramid roof structure using wooden horses. As the support of the wooden horses, there are iron columns based on natural stone. The iron material differentiates it from other materials in mosques where the use of wood is dominant. This is reinforced by Setyowati (2007) which explains that the iron material in the patio building is a different material from the mosque and its surrounding buildings, which are predominantly wood and brick without plaster. The difference in the structure of the foyer and liwan is clearly visible in the absence of a dividing wall on the foyer so that the free open space is different from the liwan which has a 2 stone brick wall. Therefore the roof structure in the pyramid is only supported by wooden columns, not supported by walls, so it can be said that the structure on the porch uses the tectonic principle, namely the column as a support for the single roof load.

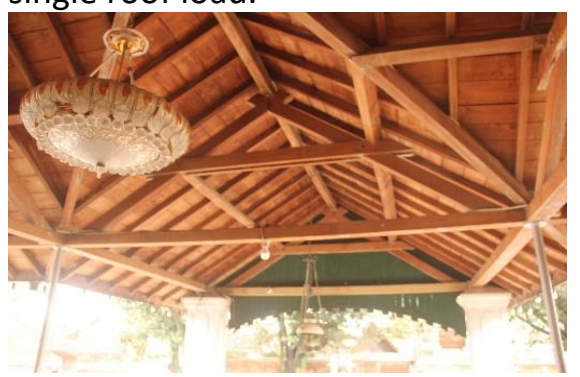

Picture 6 Sawbuck of limasan roof

Source : Personal Dokumentation 


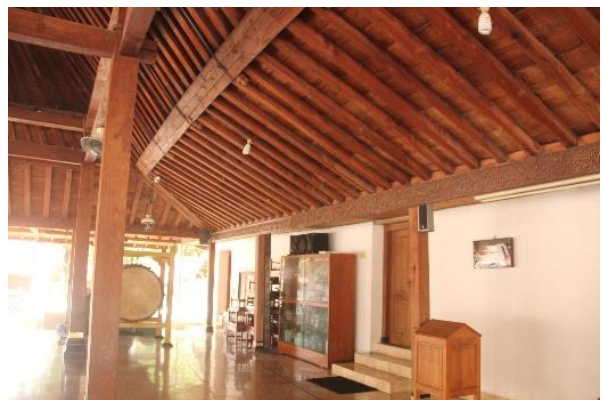

Picture 7 Soko Pangarep

Source : Personal Dokumentation

Mataram Gedhe Mosque predominantly uses wood as the main building material compared to other materials. Wood material is indeed commonly used in buildings in Java because of the availability of materials that are easy to find and installation that is not too complicated. According to Damanik (2005) explains that wood as a building material has certain strengths, especially regarding physical / mechanical properties. By knowing the strength for a certain type of wood, consumers will choose the right type of wood according to usage.

\section{Study of Spatial Planning in Mosque Room Patterns}

As a building that has the main function of worshiping a large number of Muslims, it certainly has differences in building design that does not involve large numbers of users. Therefore, the pattern of space in the mosque that has occurred in the Mataram Gedhe Mosque is of course inseparable from the design factor. Rema N (2020) argues that traditional spatial patterns in traditional architecture reflect the life of the surrounding community. Thus it is not surprising if the spatial pattern in the mosque is not only influenced by the mosque topology in general but also from the influence of the life of the surrounding community.

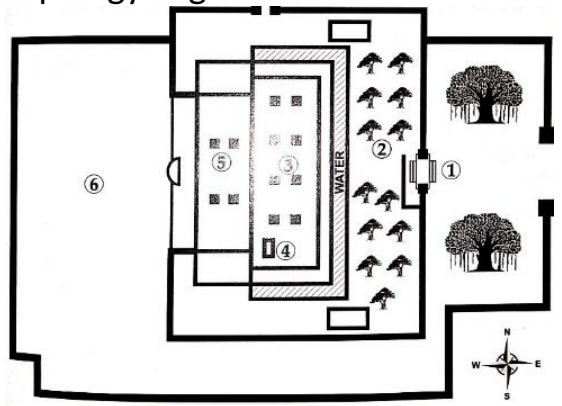

Picture 8 Siteplan of Gedhe Mataram Mosque

Sumber: The massage of panembahan senopati king of mataram Islamic kingdom

The main building which functions for prayer has the highest room in the hierarchy of space, which is in the pulpit or the place of the priest. Whereas after that there is room for the congregation or congregation. In this room, it is still divided into 2 parts, namely for the male congregation and the female congregation. This is reinforced by Rema N (2020) who explains that traditional architecture is closely related to religion as a form of cultural wisdom.

Then if you look at the building foyer and patio which functions to accommodate the congregation if the main prayer room is full as well as a communal space outside of worship has a hierarchy of space as well. The main room in this part of the building is a foyer or pendhopo, while other rooms such as a patio with a pool and a place for ablution have a function as a support for the main room. This is because the mosque must always be in a holy condition because when the congregation enters the mosque room, they have to clean 
themselves through the pool or place of ablution first. In general, the nature of internal space can be divided into 3 categories, namely public, semi-private, and private. This is reinforced by Pramesiwara $\mathrm{H}$ (2019) which explains that space in architecture can be divided into 3 parts based on the type of use, namely public, semi-private, and private spaces.

Law Number 26 of 2007 concerning spatial planning can take the meaning that the layout of the mosque is a form of structure from the mosque area which is a place for humans to carry out activities in a mosque which hierarchically has a functional relationship. In fact, according to Syamsiyah, et al. (2019) the layout of the mosque (inner and outer space) affects the formation of spatial patterns that lead to the sustainability of the audial comfort of a mosque. Based on this, the discussion of the room pattern of the mosque is important because it has a strong functional role. The inner space in particular is very important to be discussed because it is directly related to the activity of the user in it. So that if the space is well formed, user comfort will increase and vice versa. This is because architecture is a science that studies form and space. Space here includes a complex meaning, because architecture in principle consists of elements of space, beauty, functionality and strength Vitruvius (1914).

\section{Space Zoning}

Based on Law No. 26 of 2007 Zoning as part of spatial planning is an effective way to control and regulate the requirements for spatial use and control provisions that are compiled for each designation block / zone. Zoning in architectural design has an important role because zoning has the aim of spatial planning with other elements that can provide harmony in internal spatial planning. This is reinforced by Wahyuningtyas A (2015) which explains that the purpose of zoning arrangement is to create a spatial layout.

Pramesiwara H (2019) which explains that space in architecture can be divided into 3 parts based on the type of use, namely public, semi-private, and private spaces. Based on this, the zoning in the Mataram Gedhe Mosque is as follows:

1. Public

Zoning spaces that have public characteristics in the Mataram Gedhe Mosque include Emper, Serambi, and Men's prayer room. This is because the three rooms can be accessed by everyone without any rules or norms being violated.

2. Semi - Private

Zoning spaces that have a semi-private nature at the Mataram Gedhe Mosque include: prayer room for female congregation, Mihrab, and service room. These three rooms are due to the limited number of people who can access the room. Such as prayer room for female congregation which can only be accessed by female congregation, Mihrab which can only be accessed by priests when praying, and service room which can only be accessed by mosque administrators / mosque takmir

3. Private

Zoning rooms that have private characteristics are places for ablution and lavatory.

This is because the room can only be accessed alone because the user requires a high level of privacy when using the room.

\section{Circulation}

The movement of these activities leaves traces which are known as circulation. Traces can be part of the life stories of residents and people who experience them, which are a legacy for future generations (Darmayanti and Bahauddin 2019). A mosque which is a public building certainly has activities that leave a high footprint for its users. With the intensity of the use that is quite dense, the aspect of circulation of space in the mosque certainly has an important role in user comfort. 
When viewed from the inside and outside layout of the Mataram Gedhe Mosque, it allows congregants to enter the mosque from a variety of existing doors. This is indeed a characteristic of mosques in Indonesia which have wide and wide open access with doors from various corners of the mosque.

\section{Openings}

Doors, windows and vents are openings in a wall in a building that enter light and air into the room. Doors, windows and ventilation evolve over time and in all areas, but their main purpose is to introduce sunlight into the room. Openings are elements that can modify the outside climate into the building. Philips and Gardner (2004) in Dahniar (2012: 7-12). Openings are an important element in a building because they are directly related to the temperature, lighting and humidity of the air in the building. A good opening in a building makes the building healthier because the air circulation in the room is smooth as well as sunlight that can optimally enter the room.
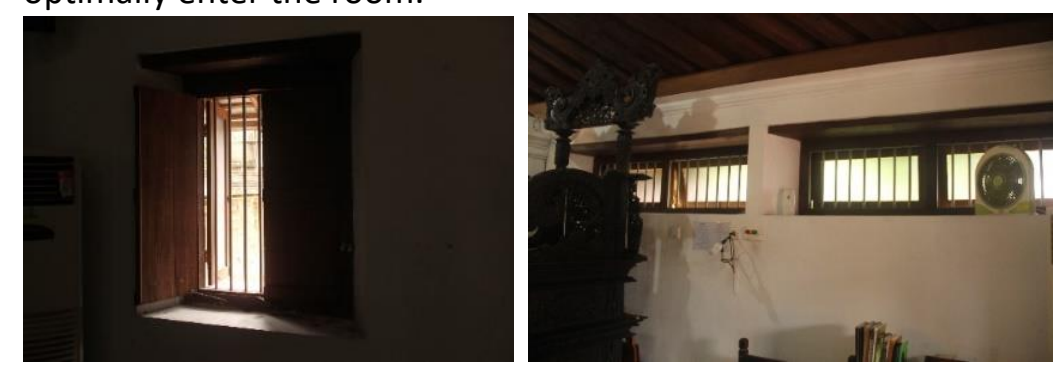

Picture 9 Windows

Source : Personal Dokumentation

Vidiyanti (2018) states that the role of light openings in a building contributes to creating good quality natural lighting. The quality of good natural lighting is inseparable from the distribution of light entering through the window (opening) and the orientation of the direction of the opening. The wider the opening, the more light will enter the room. The quality of good natural lighting also affects the location of the openings in the direction of the sunlight. At the Mataram Gedhe Mosque, openings in the mosque can be found in the main building, which is the building for prayer. Because the building's foyer and patio are semi-open like a pavilion, so there are no openings. In the main building, the opening of the mosque is located in 2 parts, namely on the side and the roof on the roof. On the side of the opening in the form of a window which in addition to functioning as the entry of light also functions to enter the wind so that fresh air can enter. Meanwhile, the opening at the top of the roof is a glass sheet that only allows light to enter the room.

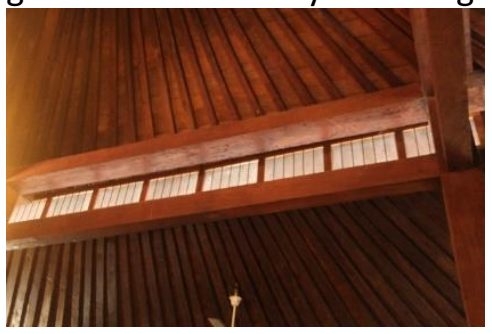

Picture 10 Boven

Source : Personal Dokumentation

\section{Ornament Detail}

Meaning of ornament according to Danna Marjono and Drs. Suyatno, in his book Fine Arts Education. Ornaments are basically decorations found in a place that are adjusted to the harmony of the situation and conditions. Ornament means decoration that is well arranged in 
a certain field or outside a certain field in order to achieve a goal of beauty. Ornaments are often used to decorate buildings to beautify buildings. Especially in traditional architecture, where there are often carvings in the corner of the building to add to the artistic value of the building. In addition, there are often statues and sculptures that have philosophical meanings in buildings which are also used to beautify the building.
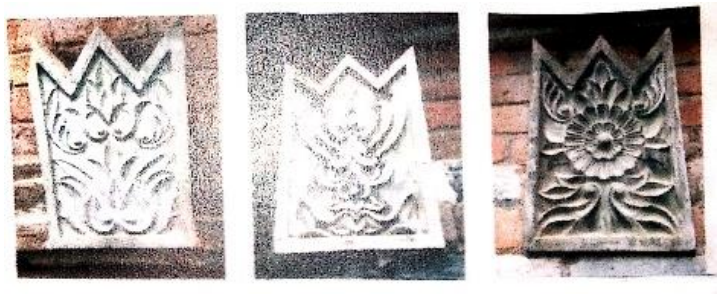

Picture 11 Ornament in the wall of Gedhe Mataram Mosque

Source : The massage of panembahan senopati king of mataram Islamic kingdom

In general, ornaments do not enter into building elements because they have different characteristics. Building elements are a constructive part of a building such as columns, walls, roofs, etc. Meanwhile, ornament is a decoration contained in building elements, both attached and separate. According to Supriyadi B (2008) explaining that traditional Javanese buildings, the ornaments on a building / mosque are grouped into several parts. Exterior ornament has the meaning of all forms of ornament or decoration either attached to or attached to the outside of the building directly or indirectly which supports the function and aesthetic value of the building and can summarize its general and comprehensive characteristics, in order to provide special characteristics, such as ornaments on the plastic ornaments on building fences, ornaments on consoles, ornaments on flagpoles, etc.

Ornaments on the Mataram Gedhe Mosque can be seen on the outer wall when entering the mosque complex. There are ornaments with the shape of flowers and plants carved into a rock. According to the explanation of the mosque takmir when interviewed explained that the ornament with floral motifs has a symbolic meaning, fragrance which means that a Muslim must behave well and make others comfortable. The leaf ornament motif has a symbolic meaning of flexibility and flexibility, meaning that every Muslim must be able to easily socialize with others and be able to understand the conditions of others. Natural motifs on ornaments, both plants and animals, are often used in traditional Indonesian architecture. These ornaments are often seen in carvings and sculptures. This is reinforced by Syahmi B (2019) who explains that in fact the plant ornament is one of the several ornaments that are inherent in Traditional Architecture. Ornaments are geometric or other stylized decorations, ornaments are made in a basic form from one handicraft (furniture, carvings, clothing, etc.) including architecture Indonesian Encyclopedia (1979: 1017) So, ornaments are motifs, patterns or decorations that are poured in a handicraft to add aesthetic value and meaning.

\section{Study of Tradition and Modernity}

Mosque is a building of worship, which comes from the word sajada or sujud, which means obedient, submissive and obedient. Prostration in sharia is the activity of kneeling, placing the forehead, palms of the hands and knees on the ground / place of prostration (Quradhawi, 2000). The main function of the mosque as a place of worship makes the topology of the mosque building almost the same. According to Rossy (1982) In general, type is often used to describe the overall form, structure, or character of a particular form or object. When viewed from building objects, typology is divided into three main things, namely the building site (site), building form, and the organization of the building parts.

The tradition of building a mosque is closely related to the culture of the surrounding community. Especially in the jogja community who have a strong culture of making mosques 
as buildings of worship, they are also tied to the surrounding culture. The general tradition in mosque buildings can be seen from the central configuration of the space and using columns as the support of the main building called the saka guru. This is reinforced by Hatmoko (2000) who explains that in terms of basic characteristics or character, the traditional typology of mosques is generally shown by the spatial configuration on the floor plan with a centered pattern. The central aspect that is focused on a part of this space can be seen in the main room, mosque foyer, inner courtyard, and outer courtyard. Even in the inner room, the space between the four main columns or pillars forms a special place.

Meanwhile, if viewed from the typology of the mosque building has a strong tradition in the form of buildings. This can be seen in the spatial layout which has a basic square plan form and the use of a tajug roof which was influential in Hindu culture in the past. This is reinforced by Iskandar (2004) who explains that in the typology aspect, the traditionalism of the basic form of mosque architecture is generally shown in square / square plan forms, with a foyer in front of it. The main part is the inner rectangle, which usually has four columns (soko guru) to support the roof.

Modernity can be defined as a characteristic in architecture that has a novelty which tries to release the traditional and cultural values inherent in architectural objects. According to Iskandar (2004) architectural modernity presents an ahistorical basic form, has no attachment to certain forms, unless it is based on functions in accordance with needs analysis. Indicators of modernity, including the spirit of renewal (innovation) and reinterpretation, rational, critical, a-historical, anti-symbolic, forms are born from certain multidimensional ideas / ideas, loyalty to the order, and form follows function.

The tradition at the Mataram Gedhe Mosque when viewed from the shape of the building is almost not much different from the Javanese mosque in general from the shape of the building to the roof. Then when viewed from more details such as the layout in the Mataram Gedhe Mosque, it also adopts the same internal layout as the Javanese mosque. As a traditional architectural building, the use of symbolic meaning in the form of ornament is still found in the Mataram Gedhe Mosque. There are carvings in the form of flowers and plants as certain symbolic meanings. Meanwhile, if viewed from the aspect of the structure of the Mataram Gedhe Mosque, it has a construction that is still tied to the construction of the Javanese mosque with the use of the main column or what is called the saka guru or saka pangarep or the use of wooden horse roofs, which provides evidence of the strong traditional values in the Mataram Gedhe Mosque.

Even so, the Mataram Gedhe Mosque can still be found with an element of novelty as an indicator of the modernity of architectural works. The novelty is located in the outer environment of the mosque, there are 2 wards located to the south and north of the mosque. This is very rarely found in other Javanese mosques. The ward was used as a resting place for travelers visiting Mataram Gedhe Mosque in the past. The existence of this ward is sufficient to prove that the novelty of the Mataram Gedhe Mosque is still there because in the past providing restrooms for travelers was not common. Generally, travelers rest on the porch of the mosque. The ward is made so that travelers can rest comfortably and not be disturbed by mosque activities.

\section{Conclusion}

The Gedhe Mataram Mosque as one of the architectural works that is still sustainable and can be used until now is worthy of being studied as an architectural object. As a mosque that was founded in the past, it does not make the mosque a simple building. Both in terms of 
construction and from an architectural point of view, the Mataram Gedhe Mosque as a place of worship for Muslims is still tied to the architectural tradition of Javanese mosques. With the use of ornaments in mosque buildings, it is increasingly proving that the traditions of mosques are very strong.

However, these conditions do not necessarily mean that the Mataram Gedhe Mosque has no novelty in it. Newness in architecture is an indicator of architectural modernity. In addition, the novelty in the building proves that the design of a mosque does not just swallow tradition. There is a space of novelty in the Mataram Gedhe Mosque where future architectural values can be taken in the architectural design of the present so as not to be fooled by the observe-imitate-modification method. This actually destroys the essence of architecture because the architectural design space becomes a means of imitating greetings. The correct concept is to study precedents by taking the basic principles of every novelty that exists in every architectural work.

\section{Acknowledgements}

The author would like to thank the management of the Mataram Gedhe Mosque who was willing to be interviewed and gave permission to collect research data, to the lecturers who had guided the research from beginning to end and all who had helped and supported the preparation of this research.

\section{References}

Abimuda, 2017, googleweblight.com, "Pengertian Aulturasi" wwwdosenpendidikan.com, "Pengertian dan Bentuk Akulturasi"

Arinto, Fransiscus Xaverius. 2018. "Pelestarian arsitektur berdasarkan architectural architypes melalui metode grafis." ARTEKS : Jurnal Teknik Arsitektur 3 (1):29-36.

Attoe, W, 1999 , The role of the critic, Dalam ben farmer \& hentir louw (ed.), companion to contemporary architectural thought (hal. 524-528), New york: routledge, ISBN : 0415010225

Budihardjo, Eko. 1987. Percikan Masalah Arsitektur, Perumahan, Perkotaan. Yogyakarta: Gajah Mada University Press.

Bustami, Abdul Latif."Teknik Inventarisasi Kepercayaan Komunitas". Makalah disajikan pada Bimbingan Teknis Pemetaan Komunitas Adat yang diselenggarakan oleh Direktorat Jenderal Nilai Budaya, Seni, dan Film Kementerian Pariwisata dan Ekonomi Kreatif. Sumedang, 16 Nopember 2011.

Capon, D.s, 1999, Architectural theory volume two: le corbusier's legacy. Principles of twentieth-century architectural theory arranged by category, Chichester: john wiley \& sons. Hal. 236), ISBN : 0471985899.

Corbusier, I , 1931, Towards a new architecture, new york: dover publication inc, ISBN : 0486250237

Dahniar. 2013. Tipologi Bentuk Jendela pada Rumah Tradisional Bugis di Taman Miniatur Sulawesi Selatan, Benteng Somba Opu Makassar.TEMU ILMIAH IPLBI. 
Darmayanti, T dan Azizi B. 2020. Pengaruh perubahan sirkulasi terhadap fungsi ruang di rumah Peranakan, Kampung Babagan, Lasem. Jurnal Teknik Arsitektur, Volume 5 Issue 2 pISSN 2541-0598; eISSN 2541-1217

Darmono, Maris Setyo Nugroho,. Slamet Widodo., dan Faqih Ma'arif. 2020. Analisis penurunan kualitas mutu kayu pada bangunan cagar budaya dengan metode non destructive test (studi kasus bangunan cagar budaya masjid gedhe mataram daerah istimewa yogyakarta). INERSIA, Vol. XVI No. 2, Desember 2020

Handinoto. (2012). Arsitektur dan Kota-kota di Jawa pada Masa Kolonial (2nd ed.). Yogyakarta: Graha Ilmu Yogyakarta.

Hatmoko, Adi Utomo. 2000. Teknonika dan Ekspresi Masjid Tradisional dan Kontemporer di Jawa. The Third International Symposium on Islamic Expression in Indonesian Architecture. Yogyakarta. UII.

Iskandar, M. 2004. Tradisionalitas dan modernitas tipologi arsitektur masjid. Dimensi teknik arsitektur Vol. 32, No. $2: 110$ - 118

Like, S (Mas Ngabei Renggosuryadi). (2017). Takmir masjid Gedhe Mataram Jogjakarta \& Keprajan Kraton Yogyakarta. Wawancara

Madsen, o.j, 2014, Modernity. Dalam thomas theo (ed.), encylopedia of critical psychology, New york: springer, Hal. 1199-1204, ISBN : 9781461455820

Mallgrave, h. F. (ed.), 2006, Architectural theory volume i: an anthology from vitruvius to 1870 , Oxford: blackwell publishing. (pp. 26-27), ISBN : 1405102586

Masjid Gedhe Mataram - Wikipedia bahasa Indonesia, ensiklopedia bebas. Diakses pada 3 Maret 2021. Pukul 9.00 WIB

Mondal, I, 2014, Modernity in philosophy and sociology: an appraisal with special reference to bangladesh, Philosophy and progress, 51 (1-2), 123-160, Philosophy and progress: vols. Li-lii, january-june, july-december, 2012

Neisbit, k. (ed.), 1996, Theorizing a new agenda for architecture: an anthology of architectural theory 1965-1995, New york: princeton architectural press, ISBN : 1568930531

Permana, Eka dan R. Cecep. 2010. Kearifan Lokal Masyarakat Baduy dalam Mitigasi Bencana. Jakarta: Penerbit Wedatama Widya Sastra.

Pitoyo, Agus Joko., dan Hari Triwahyudi. 2017. "Dinamika Perkembangan Etnis di Indonesia dalam Konteks Persatuan Negara." Populasi 25(1): $\quad$ 64-81.

Pramesiwara H, dkk . 2019. Pola ruang dalam pada rumah tradisional betawi. Prosiding Seminar: 39-44, ISBN 978-623-91368-1-9

Prijotomo, J. (1984). Ideas and Forms of Javanese Architecture. (-, Ed.) (1st ed.). Yogyakarta: Gadjah Mada University Press. Retrieved from 135.25.09.84

Pudjiono, drs. (2003). Masjid Gedhe Mataram. (Massam_kotagede, Ed.) (1st ed.). Yogyakarta: Dinas Kebudayaan dan Pariwisata Propinsi DIY.

Purbadi, Yohanes Djarot., Achmad Djunaedi., dan Sudaryono Sudaryono. 2019. "Kearifan Kaenbaun sebagai Dasar Konseptual pada Tata Spasial Arsitektur Permukiman Suku Dawan di Desa Kaenbaun." ARTEKS : Jurnal Teknik Arsitektur 3 (2): 187-204.

Quradhawi, A. Y. (2000). Tuntunan Membangun Masjid. jakarta: Gema Insani Press. 
Rema, N dan A. A. Gde Bagus. 2020. Pola ruang permukiman dan arsitektur tradisional kampung adat duarato. Forum Arkeologi Vol 33- No 1, (49-64)

Rossi. 1982. The Architecture of the City. Cambridge Mass: MIT Press

Rosyadi.2015. Tradisi membangun rumah dalam kajian kearifan lokal (studi kasus pada masyarakat adat kampung dukuh). Patanjala Vol. 7 No. 3 September 2015: 415 - 430

Salura, Purnama, dan Reginaldo Christophori Lake. 2014. "The architectural language of inner and outer space as observed among the Atoni tribe in the Tamkesi kampong on Timor Island." International Journal of Academic Research 6 (3).

Setyowati E., Gagoek Hardiman., dan Titien W. 2017. Akulturasi Budaya pada Bangunan Masjid Gedhe Mataram Yogyakarta. Prosiding Seminar Heritage IPLBI 2017. ISBN 978-60217090-5-4 E-ISBN 978-602-17090-4-7

Setyowati.E. (2007). Karakteristik Ruang Kawasan Dalam Beteng Keraton Yogyakarta. Forum Teknik, 3, 197-272.

Supriyadi, Bambang. 2008. Kajian ornamen pada mesjid bersejarah kawasan pantura jawa tengah. Jurnal Ilmiah Perancangan Kota dan Permukiman. Volume 7 No. 2

Syahmi, B, dkk. 2019. Penerapan ornamen arsitektur dayak pada bangunan museum kalimantan barat di pontianak. Prosiding Seminar hal:96-100, ISBN : 978-623-91368-0-2

Syamsiyah, N. 2018. Kajian perbandingan gaya arsitektur dan pola ruang masjid agung surakarta dan masjid gedhe kauman yogyakarta. Jurnal Arsitektur, Vol. 15 No. 1

Uwarna. (1987). Tinjauan selintas Berbagai jenis gapura Di Daerah istimewa yogyakarta. Akrawala Pendidikan N, no.2 Volume.

Vidiyanti, C dkk. 2020. Pengaruh bukaan terhadap pencahayaan alami dan penghawaan alami pada masjid al ahdhar bekasi. Vol 3 - No 1

Vitruvius, M. H. (1914). The Ten Books on Architecture. London: Harvard University Press.

Wahyudi, A. (2017). Penulis novel Makrifat Jawa, Ajaran Kesempurnaan Serat Centini, Galang Press, Yogyakarta

Wahyuningtyas, A dan Westi U. 2015. Pengaturan zoning sebagai pengendali pemanfaatan ruang (studi kasus kawasan preservasi budaya kotagede). Bhumi vol 1 